\title{
Production of capsular material by equine trophoblast transplanted into immunodeficient mice
}

\author{
A. Albihn ${ }^{1 *}$, R. O. Waelchli ${ }^{1}$, J. Samper ${ }^{2 \dagger}$, J. G. Oriol ${ }^{1 \ddagger}$, \\ B. A. Croy ${ }^{1}$ and K. J. Betteridge ${ }^{1 \S}$ \\ ${ }^{1}$ Department of Biomedical Sciences, Ontario Veterinary College; and ${ }^{2}$ Equine Research Centre, \\ University of Guelph, Guelph, Ontario N1G 2W1, Canada
}

A novel xenogeneic transplantation approach was used to determine whether it is embryonic or maternal tissue that produces the material that gives rise to the mucin-like glycoprotein of the equine embryonic capsule. Endometrial biopsy samples and conceptuses from six mares at days 13-15 after ovulation were prepared as $1 \mathbf{~ m m}^{3}$ grafts of endometrium, trophoblast and capsule for transplantation, alone or in combination, into various sites in 88 immunodeficient (severe combined immunodeficient or RAG $2 / \gamma_{c}$ double mutant) mice. The overall recovery rate of grafts was over $50 \%$, reaching $100 \%$ with experience and use of the renal subcapsular space exclusively. Periodic acid-Schiff (PAS) staining demonstrated capsulelike extracellular glycoprotein secretions at the graft site in 11 of 22 sites examined. Strong PAS-positive reactions (5-7 $\mu \mathrm{m}$ thick) were found in four of six sites containing trophoblast alone, five of six endometrium plus trophoblast sites, and zero of eight grafts of endometrium alone. Two recovered grafts of capsule were also PAS-positive. The secreted glycoprotein was identified as equine embryonic capsule material by using a monoclonal antibody (mAb) specific to equine capsule (mAb OC-1) in two experiments. In the first, in cryosections, this antibody bound to 19 of 19 recovered trophoblast graft secretions (including those in $\mathbf{1 2}$ from mice that had not received endometrium at any site), ten of ten recovered endometrium plus trophoblast grafts, and zero of 12 recovered endometrial grafts from mice in which trophoblast had been grafted to the same site or another site in the same mouse. In the second experiment, in paraformaldehyde-fixed sections of grafts from 11 mice, specific staining, identical to that shown by grafted capsule, was obtained with grafts of trophoblast (both alone and in combination with endometrium) but not with grafts of endometrium. These results support the contention that trophoblast is the principal source of equine embryonic capsule. In addition, they demonstrate that xenogeneic grafting is a useful means of culturing endometrium and conceptus tissues outside the mare when in vitro techniques do not suffice.

\section{Introduction}

The equine embryonic capsule, which consists of mucinlike glycoproteins, appears between the zona pellucida and the trophoblast on day 6 or 7 of gestation (ovulation = day 0 ) and persists throughout the second and third weeks of pregnancy (Marrable and Flood, 1975; Betteridge, 1989; Oriol et al., 1993a,b). After formation of the capsule, the zona pellucida is shed, leaving the capsule as an outer conceptus envelope. As a component of the

\footnotetext{
*Present address: Department of Disease Control and Biosecurity, National Veterinary Institute, SE-751 89 Uppsala, Sweden ${ }^{\dagger}$ Present address: Department of Clinical Sciences, Kansas State University College of Veterinary Medicine, 101 Trotter Hall, Manhattan, KS 66506-5601, USA

†Present address: Casa de Campo, La Romana, Dominican Republic

$\S$ Correspondence

Email: kbetter@uoguelph.ca
}

interface between the conceptus and the endometrium, the capsule is clearly of major functional importance. It is present throughout a stage of pregnancy when embryonic signals are vital for the prevention of luteolysis and when maternal resources must nourish a rapidly expanding conceptus during both its mobile and immobile phases in the uterus (Crossett et al., 1998; Stout et al., 1999; Betteridge, 2000; Allen, 2001). Analogous structures are found in several other species (Betteridge, 1989; Denker, 2000), making the understanding of the structure and function of the equine embryonic capsule of comparative interest.

It is still not clear where the material for the equine embryonic capsule originates. On the one hand, capsule production has often been considered to result from interactions between the endometrium and the trophoblast (Betteridge, 1989). On the other hand, the capsule has been described as being principally a product of the trophoblast (Oriol et al.,, 1993a). It has been 
Table 1. An outline of the three studies and four experiments in the investigation

\begin{tabular}{|c|c|c|c|c|c|c|}
\hline Study & Expt & Material(s) grafted & $\begin{array}{l}\text { Number of } \\
\text { mice }\end{array}$ & Duration (days) & Graft sites & Fixation and evaluation \\
\hline Pilot & 1 & Various* & 18 & $4,8,16$ & Various* & Bouin's; H\&E \\
\hline Histochemical & 2 & $\mathrm{E}, \mathrm{T}, \mathrm{E}+\mathrm{T}, \mathrm{C}$ & 20 & $4,8,16$ & Various* & Bouin's; PAS \\
\hline \multirow[t]{2}{*}{ Immunohistochemical } & 3 & $\begin{array}{l}\mathrm{E}, \mathrm{T}, \mathrm{E}+\mathrm{T} \\
\quad \text { multiple per mouse }\end{array}$ & 39 & $4,8,16$ & Various* & Cryosections; mAb OC1 \\
\hline & 4 & $\begin{array}{l}\mathrm{E}, \mathrm{T}, \mathrm{E}+\mathrm{T}, \mathrm{C} \\
\text { one per mouse }\end{array}$ & 11 & 8 & Renal subcapsular space & $\begin{array}{l}\text { Paraformaldehyde; } \\
\text { mAb OC 1; PAS }\end{array}$ \\
\hline
\end{tabular}

*The capsule was removed from six of the eight conceptuses by tearing with 25-gauge needles attached to tuberculin syringes. A small portion of capsule and cellular tissue from each conceptus and biopsy sample were removed and fixed in Bouin's fixative (Expts 1-3) or

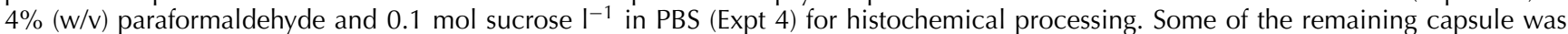
cut into small pieces for grafting in Expts 2 and 4. After removal of the capsule, conceptus tissues were halved and one half of each was infiltrated with ink and washed. Each half embryo yielded at least 20 potential grafts, approximately $1 \mathrm{~mm}^{3}$. In conceptuses at this stage of development, 'trophoblast' consists of trophectoderm lined by yolk-sac endoderm, complemented in some areas by mesoderm. Furthermore, the embryonic disc was not excluded and so some trophoblastic grafts may have included cells from the embryo proper. In Expts 1-3, India ink-stained trophoblast grafts were used unless similarly tagged endometrium was co-grafted to a given site; no such ink staining was used in Expt 4. Grafts were transplanted into the mice within $5 \mathrm{~h}$ of collection from the mare. Mice were anaesthetized by i.p. injection of 0.4-0.6 ml Avertin (Hogan et al., 1986). In each mouse, grafts were transplanted through a dorsal approach. In Expts 13 , at least two of the following graft sites were used: the right uterine horn, the right and left renal subcapsular spaces, and the dorsal aspect of the right ovarian fat pad. The right side was preferentially used to avoid the spleen, and all recipients received more than one graft. Some recipients received the same type of graft at each site; in others, the types of graft differed with site.

E: endometrium; T: trophoblast; C: capsule; H\&E: haematoxylin and eosin; PAS: periodic acid-Schiff; mAb: monoclonal antibody.

difficult to design experiments to resolve the origin of the capsule definitively because equine embryos do not produce a recognizable capsule in vitro (Betteridge, 1989; McKinnon et al., 1989). We have therefore developed a new method of xenogeneic transplantation of equine endometrium or trophoblast into two strains of mice with severe combined immunodeficiency (SCID) to address this question. SCID mice, which lack mature $\mathrm{T}$ - and B-lymphocytes and accept a wide variety of foreign tissues and cells, including equine peripheral blood leucocytes (McCune, 1988; Balson et al., 1993; Murphy et al., 1996; Greenwood et al., 1997), were used in most of the studies. RAG $2 / \gamma_{c}$ double mutant mice, a more recently developed alymphoid strain (Colucci et al., 1999), were used in the final experiment. Survival of transplanted tissue and the development of any associated products was assessed histochemically with periodic acid-Schiff (PAS) stain (Bousquet et al., 1987) and immunohistochemically, using a monoclonal antibody for equine capsule (Oriol et al., 1993a). Part of this study has been presented elsewhere in abstract form (Albihn et al., 2001).

\section{Materials and Methods}

\section{Experimental design}

All procedures used on horses and mice conformed to protocols approved by the Animal Care Committee of the University of Guelph and followed guidelines from the Canadian Council of Animal Care.

The investigation comprised three studies including four experiments (Table 1). The pilot study (Expt 1) was devoted to developing techniques. In the second (histochemical) study (Expt 2), the presence of capsule-like extracellular glycoprotein at graft sites was evaluated histochemically. The third (immunohistochemical) study evaluated the glycoprotein at graft sites with a monoclonal antibody to equine embryonic capsule in Expts 3 and 4 .

\section{Collection of equine endometrial biopsy samples and conceptuses}

Six Standardbred mares, 6-12 years of age, from the University of Guelph Equine Research Centre, served as the donors of endometrial biopsy samples and conceptuses. They were observed daily for signs of oestrus. Rectal palpation and ultrasonography with a $5 \mathrm{MHz}$ probe (Keiki LS-300, Tokyo) were used to diagnose ovulation and pregnancy, and to measure the diameter of conceptuses in utero. Oestrous mares were artificially inseminated with fresh semen on alternate days, beginning on the second day of oestrus and continuing until ovulation. The day on which ovulation was detected was designated day $0.5 \pm 0.5$, as ovulation could have occurred at any time during the preceding $24 \mathrm{~h}$.

Some of the mares were used on multiple occasions but only one endometrial biopsy sample was taken each time. These biopsies were performed transcervically, immediately before or after collection of the conceptus, using a pulling biopsy punch (Lane Medical Co, Boulder, CO) as described by Kenney (1975). Eight conceptuses (including one pair of twins) were collected on days 13.5 or 14.5 by a transcervical flush using PBS supplemented 
with $1 \%(\mathrm{v} / \mathrm{v})$ penicillin-streptomycin (Pen-Strep; Gibco, Grand Island, NY). Conceptuses ranged from 12 to $18 \mathrm{~mm}$ in diameter. The catheters used were standard endotracheal tubes of 14-18 mm inner diameter (Airecuf $^{\circledR}$, Bivona Inc., Gary, IN).

Approximately 40 potential grafts, approximately $1 \mathrm{~mm}^{3}$ and of uniform tissue composition, could be prepared from each endometrial biopsy sample. Of these, 52 potential grafts from two dioestrous mares (on days 4.5 and 7.5) and 83 grafts from six pregnant mares (days 13.5-14.5) were randomly selected and transplanted into the mice. All embryo donors were also used as donors of endometrium so that only tissues from a single donor mare were grafted into any one mouse.

\section{Mice}

The adult female mice used as graft recipients in the first three experiments were either T- and B-cell deficient C.B-17 scid/scid $(n=40)$ or T- and B-cell deficient, NK cell impaired, C.B-17 scid/scid.bg/bg $(n=43)$. The former were purchased from Taconic (Germantown, NY) whereas the latter were bred at the University of Guelph (Croy and Chapeau, 1990); both types will be referred to as SCID mice. For Expt 4, RAG $2 / \gamma_{c}$ double mutant mice, which lack all lymphocytes $\left(\mathrm{T}^{-}, \mathrm{B}^{-}, \mathrm{NK}^{-}\right.$; Colucci et al., 1999; $n=11$ ) were used. Mice were barrier-housed in microisolator cages (Lab Products Inc., Federalsburg, MD) and provided with autoclaved water and gamma-irradiated mouse chow (Charles River, St Constant, QC) ad libitum. Mice were handled only in a laminar flow hood and by personnel dressed for aseptic surgery. Some recipients $(n=33)$ were shambred by vasectomized male mice three days before use in Expts 1-3 to induce pseudopregnancy and thereby a more defined endocrinological status of the recipient. However, as no effect on graft recovery was evident for pseudopregnancy in these recipients, or for the two SCID genotypes, results from these groups are pooled.

\section{Pre-grafting tissue preparation}

Endometrial biopsy samples and conceptuses were placed in tissue culture medium (Hanks M199, supplemented with $1 \%(\mathrm{v} / \mathrm{v})$ Pen-Strep, $1 \% 1 \mathrm{~mol}$ Hepes $\mathrm{I}^{-1}, 1 \%(\mathrm{w} / \mathrm{v})$ sodium pyruvate, $10 \%(\mathrm{v} / \mathrm{v})$ newborn calf serum, all from Gibco) immediately after collection and then washed three times in fresh culture medium.

\section{Infiltration of endometrial biopsy samples with India ink}

All endometrial biopsy samples from Expts 1-3 were infiltrated with India ink (Pelikan drawing ink A, Hannover, Germany) by injection in vitro to aid in the identification of grafts at the time of their recovery from the mice and throughout histological processing (see results of Expt 1, below). Excess ink was removed by washing in culture medium before preparing the potential grafts of approximately $1 \mathrm{~mm}^{3}$.

\section{Graft preparation}

The capsule was removed from six of the eight conceptuses by tearing with 25 -gauge needles attached to tuberculin syringes. A small portion of capsule and cellular tissue from each conceptus and biopsy sample were removed and fixed in Bouin's fixative (Expts 1-3) or $4 \%(\mathrm{w} / \mathrm{v})$ paraformaldehyde and $0.1 \mathrm{~mol}^{\text {sucrose } \mathrm{I}^{-1} \text { in }}$ PBS (Expt 4) for histochemical processing. Some of the remaining capsule was cut into small pieces for grafting in Expts 2 and 4.

After removal of the capsule, conceptus tissues were halved and one-half of each was infiltrated with ink and washed. Each half embryo yielded at least 20 potential grafts, also approximately $1 \mathrm{~mm}^{3}$. In conceptuses at this stage of development, 'trophoblast' consists of trophectoderm lined by yolk-sac endoderm, complemented in some areas by mesoderm. Furthermore, the embryonic disc was not excluded and so some trophoblastic grafts may have included cells from the embryo proper. In Expts 1-3, India ink-stained trophoblast grafts were used unless similarly tagged endometrium was co-grafted to a given site; no such ink staining was used in Expt 4.

\section{Tissue grafting}

Grafts were transplanted into the mice within $5 \mathrm{~h}$ of collection from the mare. Mice were anaesthetized by i.p. injection of 0.4-0.6 ml Avertin (Hogan et al., 1986). In each mouse, grafts were transplanted through a dorsal approach. In Expts 1-3, at least two of the following graft sites were used: the right uterine horn, the right and left renal subcapsular spaces, and the dorsal aspect of the right ovarian fat pad. The right side was preferentially used to avoid the spleen, and all recipients received more than one graft. Some recipients received the same type of graft at each site; in others, the types of graft differed with site. In Expt 4, the only site used was the subcapsular space at the rostral pole of the right kidney, and grafts were of either endometrium ( $n=3$ mice), trophoblast $(n=3)$, capsule $(n=2)$, or endometrium plus trophoblast $(n=3)$.

\section{Graft recovery}

For recovery of grafts, mice were killed using $\mathrm{CO}_{2}$ followed by cervical dislocation, on days 4,8 or 16 after grafting. Six mice that died during surgery or were found dead overnight were excluded from the study. Not all graft sites contained visually recognizable donor tissue. Dissected tissues from 18 mice in the pilot study (Expt 1) were fixed using Bouin's fixative, processed for histological examination and stained with haematoxylin and eosin (Fisher Scientific, Don Mills, Ontario). In 
the histochemical study (Expt 2), dissected tissues from 20 mice were stained by the PAS reaction. In the first experiment of the immunohistochemical study (Expt 3) samples from 39 mice were embedded in optimal cutting temperature cutting compound (OCT; Miles Scientific, Toronto), frozen, cryosectioned at $5 \mu \mathrm{m}$, fixed for $10 \mathrm{~min}$ in acetone, and stained immunohistochemically. In the second experiment of the immunohistochemical study (Expt 4), to improve the quality of sections, the 11 mice were perfused with $4 \%$ paraformaldehyde-based fixative via the left ventricle under terminal anaesthesia on day 8 after grafting. Graft sites were then further fixed by $4 \mathrm{~h}$ immersion in more of the same fixative before embedding in paraffin wax and immunohistochemical processing.

\section{Immunohistochemistry}

Indirect immunohistochemical staining of $5 \mu \mathrm{m}$ cryostat sections was carried out on recovered grafts and host tissues in Expt 3 of the immunohistochemical study according to Antczak et al. (1987). At each staining session, about 20 slides of tissue were processed, together with a positive control slide prepared from a non-grafted conceptus. In brief, the tissue sections were exposed for $30 \mathrm{~min}$ to either a monoclonal antibody to equine capsule (mAb OC-1; Oriol et al., 1993a) or a polyclonal antibody (pAb) to canine parvovirus (Parrish et al., 1982) as a negative control. After exposure to the primary antibody, the tissue sections were washed three times

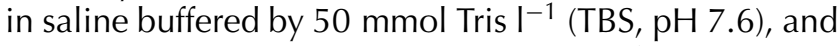
then incubated with normal goat serum for $10 \mathrm{~min}$ to block non-specific binding of the secondary antibody. The secondary antibody, peroxidase-conjugated goat anti-mouse IgG (Sigma Chemical Co., St Louis, MO), was used on the sections for $30 \mathrm{~min}$, followed by washing three times in TBS. Peroxidase reactivity was visualized by developing the sections for 40 min with amino-ethylcarbazole (Sigma), and then counterstaining them with haematoxylin for $7 \mathrm{~min}$.

Analogous staining in Expt 4 was performed on fixed, paraffin wax-embedded material. Sections $(5 \mu \mathrm{m})$ were deparaffinized and rehydrated and then incubated in 3\% $(\mathrm{v} / \mathrm{v})$ hydrogen peroxide in absolute methanol for $10 \mathrm{~min}$. After each step of the staining procedure, the slides were washed three times with PBS for 2 min each. Sections were then incubated for 30 min with $\mathrm{mAb}$ OC-1 primary antibody, which was diluted $1: 10$ with $5 \%$ rabbit serum in $\mathrm{PBS}$, or with $\mathrm{pAb}$ at the same dilution or $5 \%$ rabbit serum in PBS as negative controls. All incubations except for the one with the chromogen were done in a moist chamber at room temperature $\left(21^{\circ} \mathrm{C}\right)$. The slides were then incubated for 10 min with a biotinylated rabbit antimouse secondary antibody (64-6440, Zymed, South San Francisco, CA), diluted 1:1000 with PBS. The slides were then incubated with a streptavidin-peroxidase conjugate (Histostain $^{\text {TM }}$ Plus, Zymed) for $10 \mathrm{~min}$. The sections were then developed for 4-5 min with the chromogen, 3,3'-diaminobenzidine tetrahydrochloride.

\section{Results}

\section{Pilot study}

In Expt 1, 23 out of 52 grafts from dioestrous mares were recovered. Higher proportions of grafts were recovered from the ovarian fat pad (nine of 17) and renal subcapsular space (nine of 17) than from the uterine lumen (five of 18). Grafts were recovered at all three intervals after transplantation. Infiltration of the tissues with India ink before grafting helped recovery, especially when adhesions to surrounding tissues obscured the graft macroscopically; recovery rates were 14 of $18(78 \%)$ for the infiltrated grafts and nine of $34(26 \%)$ for the untreated grafts. Histologically, the grafts from dioestrous mares resembled the original biopsy samples except that some endometrial glands in the grafts had become dilated. The ink was confined to the intercellular spaces of the epithelium and the muscle layer; the glandular layer was usually ink-free (Fig. 1a).

\section{Histochemical study}

Endometrium. In Expt 2, seven of nine grafts prepared from the endometrium of pregnant mares were recovered. Histologically, they resembled the original biopsy samples. In addition, one graft of endometrium alone and six grafts of endometrium and trophoblast together were recovered from 21 sites to which endometrium and trophoblast had been co-engrafted. These endometrial grafts could not be distinguished histochemically from those that had been transplanted alone. All grafts of endometrium appeared viable with no signs of degeneration, irrespective of the interval from transplantation.

Trophoblast. In Expt 2, out of 11 grafts of trophoblast alone, only two were recovered, one in the uterine lumen and one from the ovarian fat pad. In addition, four grafts of trophoblast alone were recovered from 21 sites that had initially contained grafts of endometrium and trophoblast. The ink stain was not well retained by trophoblast, making these grafts difficult to localize. Histologically, the trophoblast cells had consolidated into solid balllike structures, quite unlike their appearance in intact conceptuses. However, cell viability seemed unaffected and there were no signs of degeneration. In Expt 4, in two of the three perfused recipients that had received trophoblast alone, without ink marking, the ball-like grafts were easily identified and of excellent histological quality.

Co-engrafted endometrium and trophoblast. In Expt 2, 21 graft sites received endometrium plus trophoblast. Six 

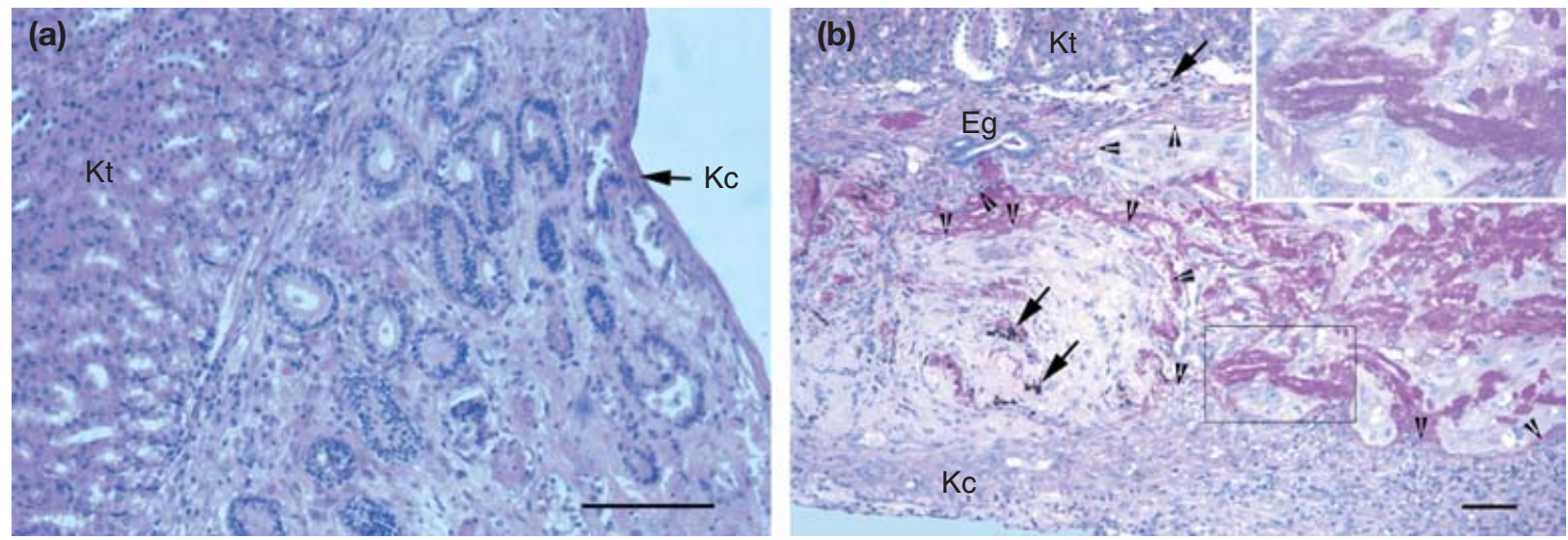

Fig. 1. Sections of grafts recovered from the severe combined immunodeficient mice used in Expts 1-3. (a) Border between an endometrial graft (to the right) and host kidney tissue at day 4 after grafting into the renal subcapsular space in Expt 2. Note the absence of cellular infiltration and the prominence of endometrial glands. Haematoxylin and eosin; Kt: host kidney tubules; Kc: host kidney capsule. (b) Co-engraftment site in the renal subcapsular space at day 8 after surgery in Expt 3. Endometrium (to the left and top) is marked with India ink (arrows). Note the strongly PAS-positive material closely related to the 'balled' trophoblast (to the right), and to the interface of the trophoblast and endometrium. Boundaries of the trophoblast graft are marked by open arrowheads. Inset: enlargement of the boxed area, showing PAS-positive secretion associated with trophoblastic cells. Periodic acid-Schiff; Eg: endometrial gland; Kt: host kidney tubules; Kc: host kidney capsule. Scale bars represent $50 \mu \mathrm{m}$.

of these showed successful co-engraftment at the time of recovery (both types of grafted tissue recovered), one site contained only endometrium, and four contained only trophoblast. Successful co-engraftment occurred in the renal subcapsular space (four of six) and the ovarian fat pad (two of six). Generally, the histological appearance of the co-engrafted tissues indicated apposition of the two tissues. Most of the grafted tissues resembled the control pre-graft samples except that trophoblast was again consolidated into a solid ball-like configuration (Fig. 1b).

Capsule. In Expt 2, eight unstained grafts of capsule were transferred into four mice. Only two grafts were recovered, one after 4 days and the other after 8 days, both from the uterine lumen. In Expt 4, however, both grafts of capsule were readily recovered from kidneys.

PAS reactivity of recovered grafts. In Expt 2, all recovered grafts of endometrium or trophoblast were examined for PAS reactivity (Table 2). A very thin $(<1 \mu \mathrm{m})$ rim of PAS-reactive material was observed on the surface of glandular epithelial cells in four of eight grafts of endometrium. However, this was not considered a 'strong PAS reactivity' in Table 2. Strong PAS-positive reactions were found in four of six grafts of trophoblast. Two of these were recovered on day 4 after transplantation, from sites originally grafted with trophoblast alone. One graft was recovered after 8 days and another after 16 days, both from co-engraftment sites at which endometrium was not found. The PAS-reactive material was mainly localized between cells and was about 5-7 $\mu \mathrm{m}$ thick. It should be noted that in Expt 2 all mice received endometrial grafts at some site.
Table 2. Recovery and strong PAS reactivity rates of various tissues in the histochemical study (Expt 2)

\begin{tabular}{llc}
\hline & \multicolumn{2}{c}{ Rates of graft } \\
\cline { 2 - 3 } Grafted tissues recovered & $\begin{array}{c}\text { Strong PAS } \\
\text { reactivity }\end{array}$ \\
\hline Endometrium only & & \\
$\quad$ from mice receiving T at another site & $7 / 9$ & $0 / 7$ \\
$\quad$ from co-engraftment $(\mathrm{E}+\mathrm{T})$ sites & $1 / 21$ & $0 / 1$ \\
Trophoblast only & & \\
$\quad$ from mice receiving $\mathrm{E}$ at another site & $2 / 11$ & $2 / 2$ \\
$\quad$ from co-engraftment $(\mathrm{E}+\mathrm{T})$ sites & $4 / 21$ & $2 / 4$ \\
Co-engrafted $\mathrm{E}+\mathrm{T}$ & $6 / 21$ & $5 / 6$ \\
Capsule & $2 / 8$ & $2 / 2$ \\
\hline
\end{tabular}

E: endometrium; T: trophoblast; PAS: periodic acid-Schiff.

In five of six sites of successful co-engraftment, strongly PAS-reactive material was also found closely related to trophoblast, and to the interface of trophoblast and endometrium (Fig. 1b).

\section{Immunohistochemical study}

In the first immunohistochemical study, using SCID recipients (Expt 3), 41 of 69 grafts were recovered 416 days after transplantation.

In sections from the positive control day 14.5 conceptus, mAb OC-1 bound to trophoblastic cell coatings. No specific binding to any cells was seen with the control pAb.

Endometrial grafts examined immunohistochemically were from recipients that had either received trophoblast 
Table 3. Recovery rates and immunohistochemical staining of various tissues in the immunohistochemical study (Expts 3 and 4)

\begin{tabular}{|c|c|c|c|c|c|}
\hline \multirow[b]{2}{*}{ Experiment } & \multirow[b]{2}{*}{ Grafted tissues recovered } & \multirow[b]{2}{*}{ Recovery rate } & \multicolumn{3}{|c|}{ mAb OC-1 binding } \\
\hline & & & Absent (-) & Faint $(+)$ & Intense $(++)$ \\
\hline \multirow[t]{8}{*}{3 (frozen tissues) } & Endometrium only & & & & \\
\hline & from mice receiving $\mathrm{T}$ at another site & $2 / 2$ & 2 & 0 & 0 \\
\hline & from co-engraftment $(E+T)$ sites & $10 / 34$ & 10 & 0 & 0 \\
\hline & Trophoblast only & & & & \\
\hline & from mice receiving no $\mathrm{E}$ at any site & $12 / 22$ & 0 & 6 & 6 \\
\hline & from mice receiving $\mathrm{E}$ at another site & $2 / 11$ & 0 & 1 & 1 \\
\hline & from co-engraftment $(E+T)$ sites & $5 / 34$ & 0 & 4 & 1 \\
\hline & Co-engrafted $\mathrm{E}+\mathrm{T}$ & $10 / 34$ & 0 & 7 & 3 \\
\hline \multirow[t]{8}{*}{4 (fixed tissues) } & Endometrium & & & & \\
\hline & from mice receiving E only & $3 / 3$ & 3 & 0 & 0 \\
\hline & from co-engraftment $(E+T)$ sites & $2 / 3$ & 2 & 0 & 0 \\
\hline & Trophoblast & & & & \\
\hline & from mice receiving $\mathrm{T}$ only & $2 / 3$ & 0 & 0 & 2 \\
\hline & from co-engraftment $(E+T)$ sites & $1 / 3$ & 0 & 0 & 1 \\
\hline & Capsule & & & & \\
\hline & from mice receiving $C$ only & $2 / 2$ & 0 & 0 & 2 \\
\hline
\end{tabular}

E: endometrium; T: trophoblast; C: capsule; mAb: monoclonal antibody.

at a different location in the same mouse (two of two), or from recipients that had orginally received endometrium co-engrafted with trophoblast but in which trophoblast was absent at the time of graft recovery (10 of 34) (Table 3). Neither the mAb OC-1 nor the control pAb reacted with these 12 endometrium grafts recovered 416 days after transplantation.

Nineteen grafts of trophoblast were recovered 416 days after transplantation. The mAb OC-1 binding intensity to material attached to trophoblastic cells was subjectively judged, under the microscope, as being absent $(-)$, faint $(+)$, or intense $(++)$. mAb OC-1, but not the control pAb, reacted with all of these grafts, particularly strongly with eight of them (Table 3 ). Table 3 shows that the range of intensity of the trophoblast staining reaction was similar whether no endometrium had been transplanted into these mice (12 grafts recovered) or endometrium had been transplanted into the same mouse either at a separate site (two grafts) or by co-engraftment with trophoblast (five grafts).

In the 10 of 34 sites from which both endometrium and trophoblast were recovered after co-engraftment, $\mathrm{mAb}$ OC -1 , but not the control pAb, reacted with all 10 , particularly strongly with three of them (Table 3 ). Reactions were confined to trophoblastic areas and, as had been seen with PAS staining, the stained extracellular material was closely related to trophoblast, or the interface between trophoblast and endometrium.

There was no detectable relationship between the thickness of immunohistochemically stained extracellular material and the interval between transplantation and recovery in any of the tissues examined.
In Expt 4, which was undertaken to improve the quality of the immunohistochemically stained sections over those obtained in Expt 3, 10 of 14 grafts were recovered (Table 3 ) and all 10 provided results that corroborated those of both Expts 2 and 3. Grafts recovered from the perfused recipients were of excellent histological quality and, with PAS, stained like their respective tissues before grafting. Capsule, both before and after grafting (Fig. 2a and $b$, respectively) stained strongly with $\mathrm{mAb}$ OC-1. No such staining was seen in either type of negative control either before or after grafting (illustrated for omission of $\mathrm{mAb}$ OC-1 in Fig. 2c). The mAb OC-1 stained material within grafts of trophoblast alone in a manner that was comparable with the staining of grafts of capsule alone (cf Fig. $2 b$ and d). Again, this staining was specific, not being seen with the control pAb (Fig. 2e), nor when the primary $\mathrm{mAb}$ was omitted (not illustrated). No such staining with $\mathrm{mAb}$ OC-1 was evident in grafts of endometrium alone. In the trophoblast plus endometrium sites, the trophoblast, but not the endometrium, stained specifically with $\mathrm{mAb}$ OC-1, as in grafts of the respective tissues alone.

\section{Discussion}

The most important finding of this xenogeneic tissue grafting investigation is that trophoblast alone is a major source of material produced in vivo that strongly resembles the equine embryonic capsule immunohistochemically and histochemically. Furthermore, interactions between equine endometrium and trophoblast are not essential to induce the production of this capsule-like material. 

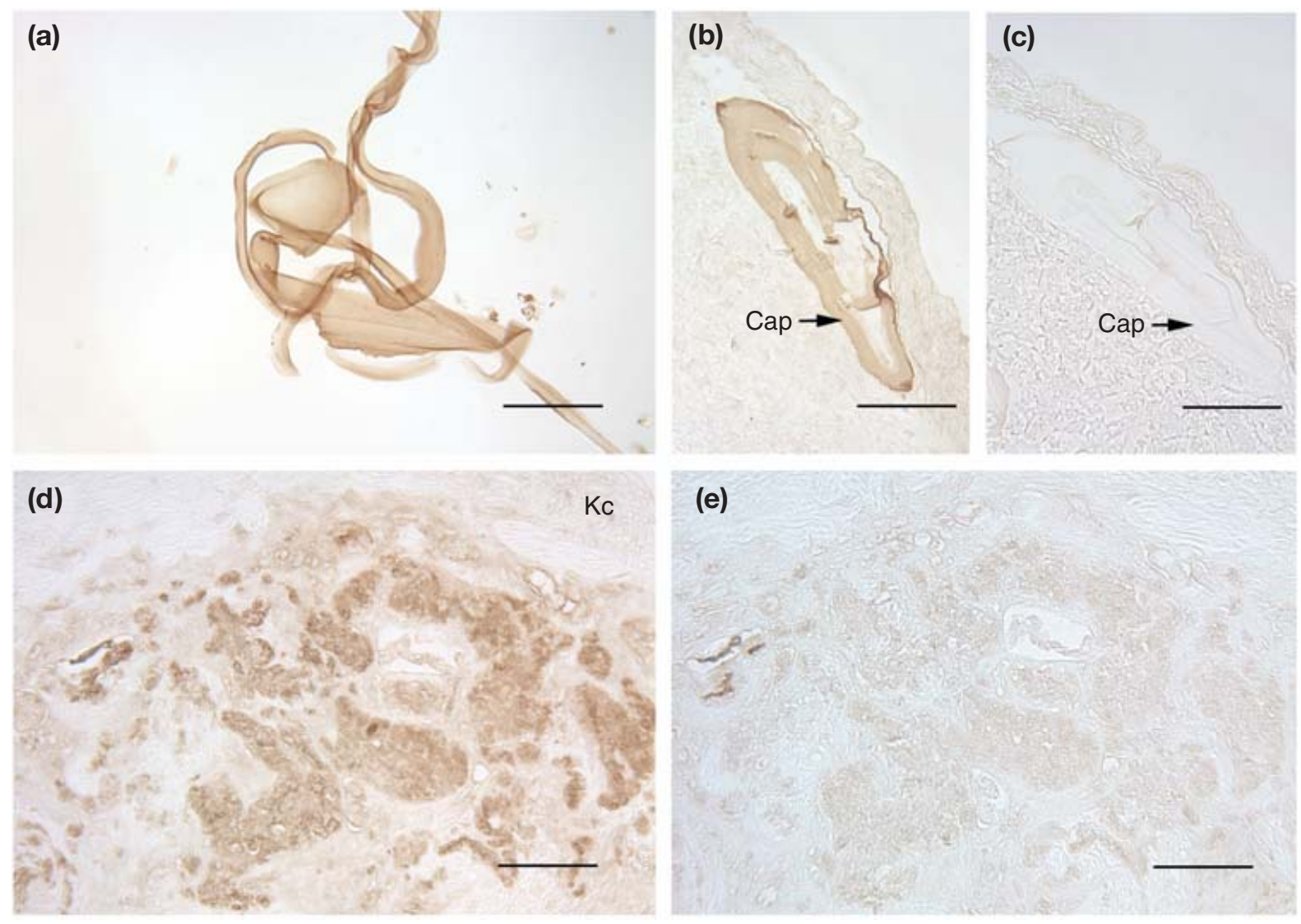

Fig. 2. Sections of capsule and grafts recovered from the renal subcapsular space of RAG2/ $\gamma_{c}$ double mutant mice in Expt 4 . (a) Capsule from the day 14.5 conceptus used to prepare grafts in Expt 4, before transplantation, stained with mAb OC-1. (b) Capsule (Cap), from the same day 14.5 conceptus as in (a), recovered at day 8 after transplantation and stained with $\mathrm{mAb}$ OC-1. Note the brown staining by diaminobenzidine of the capsule graft but not the host kidney tissues (renal capsule to the right, kidney tubules to the left of the graft). (c) The same capsule graft (Cap) as in (b), similarly stained but with omission of mAb OC-1 (negative control). (d) Trophoblast tissue recovered at day 8 after transplantation and stained with mAb OC-1. Unstained host kidney capsule $(\mathrm{Kc})$ is at the top border of the photograph. Diaminobenzidine-stained secretion (brown) is evident amongst the unstained trophoblastic tissue. (e) An adjacent section to that shown in (d), stained with the polyclonal antibody to canine parvovirus (negative control). Scale bars represent $100 \mu \mathrm{m}$.

After the histochemical study there remained the possibility that endometrial products, formed at different sites in the same mouse, influenced the trophoblast via the systemic circulation. The positive immunohistochemical results of Expt 3, however, with the 12 of 22 glycoprotein-producing grafts recovered from mice into which no equine endometrium had been introduced, was more convincing. However, the use of stained cryosections imprecisely defined the cells producing the reactive material. This limitation was resolved in Expt 4 by use of paraffin wax-embedded material that provided results corroborating those of Expt 3 and high-quality visualization of engrafted cells. It can therefore be deduced that the trophoblastic production of OC-1-reactive capsule-like material can proceed either totally independently of endometrial products, or under the influence of substances in the SCID or $\mathrm{RAG} 2 / \gamma_{\mathrm{c}}$ double mutant mouse that are identical to equine endometrial products. The latter alternative seems unlikely. These results are therefore consistent with the previous contention that the equine embryonic capsule is produced largely by trophoblast (Oriol et al., 1993a).

A second important finding is that the immunodeficient SCID or RAG $2 / \gamma_{c}$ double mutant mouse is a useful transplant recipient for culture of equine trophoblast and endometrium. This permits production of capsular material, which has not been achieved in vitro, and indicates better retention of cell function in the transplant model. The usefulness of immunodeficient mice was anticipated because they are known to support the growth of many kinds of normal, xenogeneically grafted cells (Murphy et al., 1996; Greenwood et al., 1997). SCID mice have previously been used to answer other questions concerning reproductive biology in laboratory and farm animals and in humans (Croy, 1993; Guimond et al., 1999; Weissman et al., 1999; Ashkar et al., 2000; Reis et al., 2000). More specifically, using later-stage equine chorionic girdle, D. F. Antczak and B. A. Croy 
(unpublished observations) have obtained evidence (MHC expression and eCG production) that equine trophoblast cells grafted into SCID mice retain function for up to 2 weeks. Initial experiments in the present study showed that endometrium from dioestrous mares, xenografted into SCID mice, maintains its morphological appearance for up to 16 days. Marking the grafts with India ink greatly enhanced recovery of equine tissue from the mice in early experiments and did not adversely affect the morphology of the endometrium. Unfortunately, however, ink was less well retained by trophoblast (the more difficult tissue to track histologically) than by endometrium (which is readily recognizable without ink marking). The site of transplantation also influenced the rate of recovery: poorest rates of recovery were obtained for grafts placed into the uterine lumen. Graft recovery was much better from the ovarian fat pad or the renal subcapsular space. For co-engraftment, only the renal subcapsular space was found to be satisfactory for maintaining the apposition of the two grafts. With experience and the use of this site, ink marking was not necessary.

Technical difficulties rather than graft rejection most probably accounted for the failure to find some grafts. These difficulties included: adhesions of surrounding tissue to the graft site; tearing of the renal capsule during surgery, compromising graft retention; and loss of intrauterine grafts, possibly transcervically or by retrograde migration through the surgical puncture into the peritoneal cavity. As several grafts from each donor sample were successfully transplanted and recovered, and because the recovered tissue showed neither inflammation nor degeneration, the present authors do not believe that grafts were lost due to poor graft quality or immunological rejection. Histological study of all grafts (other than capsule) provided evidence of retained function; grafts of endometrium, for example, contained dilated glands, indicating production and retention of a secretion. Evidence for retained function in trophoblast grafts was their voluminous secretion of PAS- and mAb OC-1-positive material. Thus, this xenogeneic transplant model proved well suited to the investigation of the cellular source(s) of capsular material.

The conceptus tissues used for grafting are described as 'trophoblast' for convenience despite the fact that all would have most probably included yolk-sac endoderm, and some may have included mesoderm and even cells of the embryonic disc. Of these tissues, however, the trophectoderm can clearly be regarded as the major secretory epithelium based on histological and ultrastructural studies (Flood et al., 1982; Enders et al., 1988, 1993). Almost all grafts of trophoblast, either alone or in combination with endometrium, showed evidence of capsular material production based on immunohistochemical findings and PAS-reactivity. As the grafts of capsule alone did not change with time in the mice, and the thickness of the capsular material produced $(5-7 \mu \mathrm{m})$ in graft sites did not increase between days 4 and 16 after transplantation, the period over which the production of this material occurred is uncertain.

It is especially relevant that OC-1-reactive material, so prominent in the strongly PAS-reactive regions associated with trophoblast, was not identified in the weakly PASreactive regions of grafted endometrium. Furthermore, in graft sites containing both trophoblast and endometrium, the OC-1 staining was closely associated with trophoblast. Thus, the capsule-like material produced by the trophoblast grafts was distinct from the PAS-reactive endometrial secretion but could not be distinguished antigenically from physiologically normal capsule in the control conceptus.

The reason that capsule-like material is detected more readily in the xenogeneic grafting system than in vitro may be related to the fact that capsular glycoproteins belong to the mucin family (Oriol et al., 1993b). Mucin glycoproteins are secreted as large glycopeptides and the gel-like mucus layer is formed later on the surface of the mucosa (Verdugo, 1991). The conditions required for the hydration and cross-linking leading to the formation of a new layer of considerable physical strength are difficult to achieve in vitro. Why this has not yet been successful is unknown, but may be due to the lack of knowledge of how uterine fluids are involved in the process (Denker, 2000). In vitro, secreted mucins may disperse into the culture medium rather than accumulate close to cells producing them. After grafting, on the other hand, the mucins may accumulate under the restraint of surrounding tissues, thereby becoming more recognizable.

The very strong evidence found in this work that the production of equine capsular glycoproteins is by the trophoblast should be useful for advancing understanding of the early embryonic development in the horse and in other species in which production of analogous blastocyst coverings are found. Furthermore, the xenogeneic grafting system used here should be a useful experimental tool for investigations in such species.

The authors thank B. Blake for careful husbandry of the mice, $\mathrm{H}$. Coates and $\mathrm{H}$. Hunter for help in preparation of samples for histology and immunohistochemistry, and T. Sullivan for help with the illustrations. The present study was supported by the Natural Sciences and Engineering Research Council, Canada, the Swedish Council for Forestry and Agricultural Research, Sweden, the Ontario Ministry of Agriculture, Food, and Rural Affairs, Canada, and the E. P. Taylor Research Foundation, Canada.

\section{References}

Albihn A, Samper J, Oriol JG, Croy BA and Betteridge KJ (2001) Production of capsular material by equine trophoblast transplanted into immunodeficient mice. In Proceedings of the Fifth International Symposium on Equine Embryo Transfer 6-9 July 2000, Saari, Finland Havemeyer Foundation Monograph No. 3 pp 60-61 Eds T Katila and JF Wade. R \& W Publications, Newmarket 
Allen WR (2001) Fetomaternal interactions and influences during equine pregnancy Reproduction 121 513-527

Antczak DF, Poleman JC, Stenzler LM, Volsen SG and Allen WR (1987) Monoclonal antibodies to equine trophoblast Trophoblast Research 2 199-214

Ashkar AA, Di Santo JP and Croy BA (2000) Interferon $\gamma$ contributes to initiation of uterine vascular modification, decidual integrity, and uterine natural killer cell maturation during normal murine pregnancy Journal of Experimental Medicine 192 259-269

Balson GA, Croy BA, Ross TL and Yager JA (1993) Demonstration of equine immunoglobulin in sera from severe combined immunodeficiency/beige mice inoculated with equine lymphocytes Veterinary Immunology and Immunopathology 39 315-325

Betteridge KJ (1989) The structure and function of the equine capsule in relation to embryo manipulation and transfer Equine Veterinary Journal Supplement 8 92-100

Betteridge KJ (2000) Comparative aspects of equine embryonic development Animal Reproduction Science 60/61 691-702

Bousquet D, Guillomot M and Betteridge KJ (1987) Equine zona pellucida and capsule: some physiochemical and antigenic properties Gamete Research 16 121-132

Colucci F, Soudais C, Rosmaraki E, Vanes L, Tybulewicz VL and Di Santo JP (1999) Dissecting NK cell development using a novel alymphoid mouse model: investigating the role of the $\mathrm{c}$-abl proto-oncogene in murine NK cell differentiation Journal of Immunology 162 27612765

Crossett B, Suire S, Herrler A, Allen WR and Stewart F (1998) Transfer of a uterine lipocalin from the endometrium of the mare to the developing equine conceptus Biology of Reproduction 59 483-490

Croy BA (1993) The application of SCID technology to questions in reproductive biology Laboratory Animal Science 43 123-126

Croy BA and Chapeau C (1990) Evaluation of the pregnancy immunotrophism hypothesis by assessment of the reproductive performance of young adult mice of genotype scid/scid.bg/bg Journal of Reproduction and Fertility 88 231-239

Denker H-W (2000) Structural dynamics and function of early embryonic coats Cells Tissues Organs 166 180-207

Enders AC, Lantz KC, Liu IK and Schlafke S (1988) Loss of polar trophoblast during differentiation of the blastocyst of the horse Journal of Reproduction and Fertility 83 447-460

Enders AC, Schlafke S, Lantz KC and Liu IK (1993) Endoderm cells of the equine yolk sac from day 7 until formation of the definitive yolk sac placenta Equine Veterinary Journal Supplement 15 3-9

Flood PF, Betteridge KJ and Diocee MS (1982) Transmission electron microscopy of horse embryos 3-16 days after ovulation Journal of Reproduction and Fertility Supplement 32 319-327

Greenwood JD, Croy BA, Trout DR and Wilcock BP (1997) Xenogeneic (bovine) peripheral blood leukocytes engrafted into severe combined immunodeficient mice retain primary immune function Veterinary Immunology and Immunopathology 59 93-112
Guimond M, Wang B and Croy BA (1999) Immune competence involving the natural killer cell lineage promotes placental growth Placenta 20 $441-450$

Hogan B, Costantini F and Lacy E (1986) Manipulating the Mouse Embryo: A Laboratory Manual Cold Spring Harbor Laboratory Press, Cold Spring Harbor, NY

Kenney RM (1975) Prognostic value of endometrial biopsy in the mare Journal of Reproduction and Fertility Supplement 23 347-348

McCune JM, Namikawa R, Kaneshima H, Schultz LD, Leiberman M and Weissman IL (1988) The Scid-hu mouse: murine model for the analysis of human hematolymphoid differentiation and function Science $\mathbf{2 4 1}$ 1632-1639

McKinnon AO, Carnevale EM, Squires EL, Carney NJ and Seidel GE (1989) Bisection of equine embryos Equine Veterinary Journal Supplement 8 129-133

Marrable AW and Flood PF (1975) Embryological studies on the Dartmoor pony during the first third of gestation Journal of Reproduction and Fertility Supplement 23 499-502

Murphy WJ, Taub DD and Longo DL (1996) The huPBL-SCID mouse as a means to examine human immune function in vivo. Seminars in Immunology 8 233-241

Oriol JG, Sharom FJ and Betteridge KJ (1993a) Developmentally regulated changes of the equine embryonic capsule Journal of Reproduction and Fertility 99 653-664

Oriol JG, Betteridge KJ, Clarke AJ and Sharom FJ (1993b) Mucin-like glycoproteins in the equine embryonic capsule Molecular Reproduction and Development 34 255-265

Parrish CR, Carmichael LE and Antczak DF (1982) Antigenic relationship between canine parvovirus type 2, feline panleukopenia virus, and mink enteritis virus using conventional antisera and monoclonal antibodies Archives of Virology 72 267-278

Reis MM, Tsai MC, Schlegel PN, Feliciano M, Raffaelli R, Rosenwaks $\mathbf{Z}$ and Palermo GD (2000) Xenogeneic transplantation of human spermatogonia Zygote 8 97-105

Stout TAE, Lamming GE and Allen WR (1999) Oxytocin administration prolongs luteal function in cyclic mares Journal of Reproduction and Fertility 116 315-320

Verdugo P (1991) Mucin exocytosis American Review of Respiratory Diseases 144 S33-S37

Weissman A, Gotlieb L, Colgan T, Jurisicova A, Greenblatt EM and Casper RF (1999) Preliminary experience with subcutaneous human ovarian cortex transplantation in the NOD-SCID mouse Biology of Reproduction $601462-1467$

Received 23 December 2002.

First decision 29 January 2003.

Revised manuscript 14 February 2003.

Accepted 14 February 2003. 